\title{
Dendrocentric mythopoeic paradigm in the poem "Italy - to Lord" by Jane Draycott and the specificity of the translation into Russian
}

\section{[Дендроцентрическая мифопоэтическая парадигма в стихотворении Джейн Дрейкотт «Из Италии - к Господу» («Italy - to Lord») и специфика перевода текста стихотворения на русский язык]}

\author{
Nataliya A. Kindrya - Andrei V. Mitichkin
}

DOI: 10.18355/XL.2019.12.03.11

\begin{abstract}
The article is devoted to the problem of faithful translation of a poetic piece with mythopoeic subtext. If one requires doing a comprehensive analysis and comparison of mythologemes in different Indo-European languages in order to find unapparent affinity of words in distantly related languages (for instance, English and Russian), lexico-semantic universals distinguished by M.M. Makovsky are very much applicable. At the moment, the concept of lexico-semantic universals is mostly used for scientific purposes. However, the practice of using such concepts for applied purposes is quite uncommon.

The purpose of our research is to make an appropriate translation of J. Draycott's "Italy - to Lord" with careful consideration of mythological subtext, using the lexicosemantic universals in order to adequately reflect the mythological semantics and the meaning implied by the author.

In order to do so, we've distinguished the conceptual base behind the Draycott's poem - the World tree myth. Beyond that, we've singled out the lexis group associated with this mythologeme: oak, tree, forest, wood (wooded). Afterward, we've translated the poem into Russian, trying to abide by the associated lexis group. Based on Makovsky's comparative dictionaries of the Indo-European languages and supplementary literature, we've brought together the nine metaphorical meanings of the World Tree mythology, identified them in the associated lexis of the original text and the text of our translation and compared them.

We have concluded that, having underwent the process of translation, the text still maintains the semantics of the World tree as a metaphor for the Vertical of Fire, Periphery, Other World, Deity, phallic symbols and actions, Old Age and their loss due to barbaric extermination of forests; however, the semantics of The Middle as a symbol of holiness and the starting point, and also the semantics of the Divine Mind and the Universe are lost.

To recover the lost layer of meaning in the translation we used the following methods: additional manifestation of the lost meanings through the associated lexis group (The Snake is a symbol of power, but also a symbol of the Universe); applying the lost meanings to lexemes not associated with the World tree mythologeme (Eng. Logic > Russian razum > Bozhestvennyy razum (Divine Mind); actualization of cultural symbolism (the cross is a crossing point of the Vertical, represented by Russian lexemes les (forest, wood), derevo (tree) and the Horizontal, represented by Russian lexemes Bezdna (Deep), Mater' (Mother); the cross is meant to represent the lost meaning of The Middle; introduction of the lexis alluding to the cultural symbolism (the symbol of Universe is a circle with a dot, hence the usage of a Russian lexeme krugom (all around); verbalization of the unverbalized metaphorical layer of the original text (Russian lexemes dom (house), shum (noise), poseredi (amidst), utroba $(w o m b)>$ The Middle.
\end{abstract}


Keywords: translation, English language, Russian language, Indo-European etymology, mythopoeic paradigm

\begin{abstract}
Аннотация
Статья посвящена проблеме адекватного перевода поэтического произведения с мифопоэтическим подтекстом. Для комплексной оценки и сравнения мифологем в индоевропейских языках подходят лексико-семантические универсалии М.М. Маковского, позволяющие находить родство слов из неблизкородственных языков, к которым относятся английский и русский языки. Однако пока лексико-семантические универсалии используются главным образом в научно-исследовательских, а не прикладных целях, в рамках которых существенного опыта их применения нет.

Цель исследования: выполнить перевод на русский язык стихотворения Д. Дрейкотт «Из Италии - к. Господу» с мифологическим подтекстом, используя лексико-семантические универсалии с целью максимально адекватной передачи мифологической семантики и индивидуально-авторских смыслов.

С этой целью нами была выявлена концептуальная основа произведения - миф о Мировом древе, а так же группа лексики, ассоциированная с данной мифологемой: англ. oak «дуб», tree «дерево», forest «лес», wood (wooded) «дерево, лес». Затем мы выполнили перевод стихотворения на русский язык, стараясь сохранить в нем ассоциированную группу лексики, которая, тем не менее, сократилась до 2 лексем (русск. дерево, лес). Опираясь на сравнительносемасиологические словари индоевропейских языков М.М. Маковского и дополнительную литературу, мы выделили девять метафорических значений мифологемы «Мировое древо», а затем выявили их в группах ассоциированной лексики в текстах оригинала и перевода и сравнили.

Нами обнаружено, что в тексте перевода сохраняется семантика Мирового древа, как метафоры Огненной вертикали, Периферии, Потустороннего мира, Божества, фаллических символов и действий, старости, а так же их потери в связи с варварским уничтожением лесов; утрачивается семантика Середины, как символа святости и точки отсчета, Божественного разума, Вселенной.

Для восполнения утраченных смыслов в тексте перевода мы использовали следующие приемы: дополнительное выявление утерянных смыслов в группе ассоциированной лексики (Змея символ силы, но и символ Вселенной); придание утерянных значений лексемам, не ассоциированным с мифологемой «Мировое древо» (англ. Logic «логика, алгоритм» > русск. разум > «Божественный разум»); актуализация культурологической символики (крест пересечение Вертикали, представленной лексемами русск. лес, дерево и Горизонтали, представленной лексемами русск. бездна, матерь является метафорой утерянного значения «Середина»), а так же введение в текст эквивалентной ей лексики (символ Вселенной - круг с точкой > лексемаэквивалент русск. кругом); вербализация невербализованных метафор оригинального текста с помощью введения в текст новых лексем (лексемы русск. дом, шум, посереди, утроба > «Середина»).
\end{abstract}

Ключевые слова: перевод, английский язык, русский язык, индоевропейская этимология, мифопоэтическая парадигма

\title{
Введение
}

Наличие мифологического и культурологического подтекста в поэтическом произведении a priori превращает и без того нелегкий процесс перевода в труднейшую задачу. Наличие и использование методологического инструмента для комплексной оценки мифологем со сравнением их значений в языках оригинала и перевода могло бы способствовать более адекватной передаче мифологической семантики и индивидуально-авторских смыслов, поэтому 
исследования, направленные на создание такого инструмента или оптимизацию его применения в практике перевода являются весьма актуальными.

В конце 20 и начале 21 века появились новые методы этимологического анализа, которые существенно дополнили и обогатили традиционные фонетические законы, разработанные ранее. Это метод множественной этимологии В.Н. Топорова, а так же блок семантических законов М.М. Маковского: отбрасывание табуирующих отрицаний и табуирующих преформантов в слове, учет древней символики, учет семантических закономерностей, метод лексико-семантических параллелей (Makovsky, 1989, 1992, 2012). На основе этих методов созданы матрицы - лексико-семантические универсалии в индоевропейских языках (далее - ЛСУИЯ), которые позволяют выявлять глубинное родство слов даже из неблизкородственных языков, к которым относятся английский и русский языки (Makovsky, 2007, 2013).

Эти данные позволяют предположить, что ЛСУИЯ можно использовать в качестве эффективного инструмента для комплексной оценки мифологем в процессе перевода поэтических произведений с мифологическим подтестом. Проблема заключается в том, что в настоящее время ЛСУИЯ используются главным образом в научно-исследовательских целях и лишь в единичных случаях - для решения прикладных задач перевода (Kretova, 2012a), поэтому существенного опыта их применения в практической области нет.

Цель исследования: выполнить перевод с русского языка на английский язык поэтического произведения с мифологическим подтекстом, используя ЛСУИЯ и оценить эффективность их применения, как методологического инструмента комплексной оценки мифологем с позиции адекватности передачи мифологической семантики и индивидуально-авторских смыслов.

\section{Материалы и методы}

В качестве фактического материала - поэтического текста, имеющего яркий мифологический подтекст выбрано стихотворение британской поэтессы и переводчика-медиевиста Д. Дрейкотт «Из Италии - к Господу» (Draycott, 2016: 12).

Для достижения цели исследования поставлены следующие задачи.

1. С помощью культурологического анализа мифологической символики (Makovsky, 1996) определить в тексте оригинала доминирующую мифологему и группу лексики, ассоциированную с ней - мифопоэтическую парадигму (Kretova, 2012b: 141).

2. Перевести текст с аглийского языка на русский язык, сохраняя по возможности ассоциированную группу лексики.

3. Создать перечень метафорических значений доминирующей мифологемы, используя ЛСУИЯ и дополнительную литературу. Для решения этой задачи использовались сравнительно-семасиологические словари индоевропейских языков в трудах по этимологии М.М. Маковского (Makovsky, 1989, 1992, 1996, $2002,2007,2012)$ и результаты лексико-этимологических исследований его учеников (Grigorova, 2008, Batueva, 2008, Vorfolomeeva, 2012); исследование германской космогонии Т.В. Топоровой (Toporova, 1994); культурологическое исследование концепта Мирового древа О.С. Тумановой (Tumanova, 2001); классический труд по индевропеистике Т.В. Гамкрелидзе и Вяч.Вс. Иванова (Gamkrelidze, 1984); этимологические словари современного английского языка (Makovsky, 1999, 2005, Pattridge, 2009, Hoad, 2000), современного немецкого языка (Makovsky, 2004), протогерманского языка (Kroonen, 2013), французского языка (Wartburg, 1969, Gamillscheg, 1969), латинского языка (Ernout, 2001), русского языка (Semenov, 2003). В ряде случаев привлекались данные из 
истории археологии Лондона (Perring, 1991), исследований древесной символики в русской лингвокультуре (Gerasimenko, 2015).

4. Выявить метафорические значения доминирующей мифологемы в ассоциированной группе лексики текстов оригинала и перевода и сравнить их.

5. При утрате значений доминирующей мифологемы в тексте перевода разработать приемы семантического восполнения утерянных значений и смыслов.

6. Определить прочие мифологемы и их значения в тексте оригинала, выполнить их адекватный перенос в текст перевода; изучить и дать интерпретацию мифологической фабуле произведения.

7. Дать качественную оценку эффективности применения ЛСУИЯ, как инструмента комплексной оценки и сравнения мифологем по их влиянию на адекватность передачи мифологической семантики и индивидуально-авторских смыслов в процессе перевода.

\section{Результаты исследования}

В тексте оригинала (таблица № 1А) выявлена концептуальная основа произведения - космогонические мифы о божественном сотворении Вселенной и Мировом древе, как ее дендрологической модели (Makovsky, 1996: 99).

Таблица № 1. Сравнение оригинального текста стихотворения Д. Дрейкотт «Из Италии - к Господу» с текстом его перевода на русский язык

\begin{tabular}{|c|c|}
\hline А. Текст оригинала & В. Текст перевода \\
\hline $\begin{array}{l}\text { It's dark in here and forest } \\
\text { green: Britannica, } \\
\text { sixteen oak trees in a London living } \\
\text { room, } \\
\text { the little girl, my mother, in the book- } \\
\text { case glass. } \\
\text { Italy, Ithaca, Izmail, Japan, each page } \\
\text { a mainsail, } \\
\text { turning, HMS Discovery - none of } \\
\text { the rivers } \\
\text { of southern Italy is of any great im- } \\
\text { portance. }\end{array}$ & $\begin{array}{l}\text { В лесной утробе Лондон, дом; тьма, } \\
\text { зелень, дерева кругом и на } \\
\text { шестнадцати дубах } \\
\text { В гостиной шумит листва; посереди - } \\
\text { девчушка-гном с «Британникой» в } \\
\text { руках; } \\
\text { Шкаф с книгами распахнут, на стекле } \\
\text { - из детства матери виденья: звуки, } \\
\text { краски... } \\
\text { Италия, Итака, Измаил, Япония; } \\
\text { страницы - паруса; даль, ветер, скрип } \\
\text { оснастки; } \\
\text { Лист перевернут, «Эйч-эм-эс } \\
\text { Дискавери»! Виват! А дальше - скука, } \\
\text { недоразумение: } \\
\text { «На южных территориях Италии нет } \\
\text { рек великих по размерам и значению». }\end{array}$ \\
\hline $\begin{array}{l}\text { Like birds on a long-haul flight, let } \\
\text { not seas } \\
\text { or deserts, cliffs or icy mountain-tops } \\
\text { impede you. Jews, Kabîr, Kabul, } \\
\text { Kaffir, } \\
\text { from up here all seems clear (all } \\
\text { evilin the world's } \\
\text { ascribed to Maya or illusion), then } \\
\text { home at last } \\
\text { returned from all those navigable } \\
\text { miles }\end{array}$ & $\begin{array}{l}\text { Как птицам в долгих перелетах тебе } \\
\text { мешают, если не моря или пустыни, } \\
\text { Так скалы голые да шапки ледяные, } \\
\text { надетые как копья на горные вершины. } \\
\text { Евреи, Кабир, Кабул и Каффир, а } \\
\text { дальше уж понятно: «Всё мировое зло } \\
\text { От наговоров Майя иль иллюзии». Зло } \\
\text { - сила, но тебе безмерно повезло: } \\
\text { К семье и близким возвратиться, } \\
\text { одолев едва-едва солёные как пот } \\
\text { морские мили; } \\
\text { Вновь обрести очаг, знакомые края, } \\
\text { где ты был свой и все тебя любили; }\end{array}$ \\
\hline
\end{tabular}


to Lichen, Linnet, Logic, London, to find

a century has passed, the forest's

cleared,

the animals all bared and scorched,

the gold

all brought to light. I look into the

glass,

discover there myself in dense shade,

deep

and shadowy as on any wooded is-

land.
И Лондон, где твой род и его сила, семя; и разум - тот, что с миром не вразрез...

А что ж вокруг? Сменилось тихо время, столетие прошло; секут под корень лес,

Зверье обнажено, обожжено,

бесплодны земли; их душу - золото уж вынули давно.

Но у меня в руках билет счастливый: смотрю я на стекло, как в чудное окно И вижу в нем себя сквозь плотный сумрак в тенистой бездне девственных лесов;

Мне явлено грядущее, там у меня есть место: какой-то из лесистых островов.

Рассмотрим подробнее метафорическую символику Мирового древа, как главного мифопоэтического образа произведения.

1. Мировое древо является метафорой Вселенной.

Божество сотворило пространство и материю Вселенной из бесструктурного Хаоса в соответствии со своим замыслом, в основе которого была Гармония (Tumanova, 2001: 24). Вселенная представлялось древним германцам в виде сферы, состоящей из двух полусфер (Toporova, 1994: 23). У сферы есть неподвижная центральная ось, расположенная вертикально. Относительно нее выпуклая полусфера (мужское начало) является верхом, вогнутая полусфера (женское начало) - низом. Мировая ось - взметнувшийся вверх столб Огня или Огненная вертикаль. Мировая ось структурирует по вертикали пространство Вселенной, которое состоит: из Верхнего мира (Небо); Среднего мира людей на круге земном - суше, по периферии которой плещется Вода; Нижнего мира под сушей и водой (Makovsky, 1996: 134). Вселенная пронизана Светом и Звуком проявлениями Слова - символа божественной мысли, Логоса (Makovsky, 2005: 97). Трехчастная модель определяет пределы Вселенной в вертикальной проекции (Toporova, 1994: 34). С позиции культуры она отражает идею взаимодействия мужского и женского начал Вселенной с лежащим между ними миром людей (Tumanova, 2001: 13).

Морфология дерева повторяет трехчастную структуру пространства Вселенной и является его метафорой (Makovsky, 1992: 69). Крона - Верхний мир, где селятся птицы и живут боги. Пространство между подножием и кроной Средний мир людей и наземных животных. Корни - Нижний мир хтонических животных и растений, душ умерших.

Точка контакта ствола с поверхнностью суши - сакральное место встречи Вертикали (мужского начала) и Горизонтали (Женского начала) - центр Среднего мира и центр сферы-Вселенной (Toporova, 1994: 29). В пространстве Среднего мира, где живут люди Мировое древо - всегда Центр (ствол) и всегда граница с Периферией (Tumanova, 2001: 26), так как размер его кроны определяет пределы пространства Вселенной в горизонтальной проекции (Toporova, 1994: 34). Чем более освоен и обжит мир людей, тем шире крона (Tumanova, 2001: 20). Двучастное членение пространства Вселенной в горизонтальной проекции динамично и определяется движением познания и развитием культуры (Tumanova, 2001: 25, 32, 33).

XLinguae, Volume 12, Issue 3, June 2019, ISSN 1337-8384, eISSN 2453-711X 
Вместе с пространством появилось неотделимое от него Время, которое древние сравнивали с Огнем (и.-е. *uer- «огонь», но и.-е. *uer-men «время») и Водой (тох. А war «вода») (Makovsky, 1996: 92). У Мирового древа из скандинавской мифологии - ясеня Иггдрасиля часть корней растет вверх, а ветви кроны ближе к земле обращены вниз; вместе они образуют замкнутый «на себя» единый пространственно-временной континуум, в котором свернута вся информация о Вселенной от ее рождения до гибели (Toporova, 1994: 26, Tumanova, 2001: 13). Сравним значения «дерево» и «Вселенная». Авест. anghu- «Вселенная», но и.-е. *a(n)g- «дуб»; гот. fairhvus «Вселенная», но и.-е. *perk- «дуб»; русск. мир, но арм. mair «ель»; др.-англ. weorold «Вселенная», но авест. varesa «дерево»; др.англ. wang «Вселенная», но др.-инд. vangah «дерево» (Makovsky, 1996: 102). И.е. *perk «дуб», но др.-англ. feorh «Вселенная» (Makovsky, 2007: 48). Англ. wood «дерево, лес» (< и.-е. *ued-/*ueid- «соединять»), но прусск. swetan «Вселенная» (Makovsky, 1996: 165).

2. Мировое древо является метафорой Огненной вертикали.

Дерево символизировало вздымающийся вверх столб пламени, а лес - его пляшущие языки.

Сравним значения «огонь, гореть» и «дерево».

И.-е. *ag- «огонь» (Makovsky, 1992: 32, 2007: 39), но также и.-е. *ag-/*bhag«дуб» (Makovsky, 2012: 104). Лексема англ. oak «дуб» соотносится с и.-е. корнями *a(i)g- «дуб» и *ak- «разрывать» (Makovsky, 1999: 41), «гореть» (Makovsky, 2002: 67). И.-е. *ag- «огонь», но русск. огонь (Grigorova, 2008: 18). И.-е. корень *ter-/*der- «огонь, гореть», но и «дерево» (Grigorova, 2008: 18). И.е. корень *ter-/*der- «дерево», но англ. treе «дерево» и русск. дерево (Makovsky, 1992: 74, 2012: 104). И.-е. *ter- «дерево», но и.-е. *tris- «три» - число, олицетворяющее гармонию трехчастной структуры Вселенной (Makovsky, 1999: 381). И.-е *ued-/*ueid- «рассекать/гнуть» (Makovsky, 2007: 44), «Гореть» (Makovsky, 2002: 65), но др.-англ. widu, др.-сев. viðr, др.-ирл. fid, англ. wood «дерево, лес» (Makovsky, 1999: 400).

Считается, что лексема англ. forest «лес» заимствована из ст.-фр. языка (ст.-фр. forest «лес»; фр. forêt «лес») и имеет отношение к латинскому словосочетанию silva forestis (Pattridge, 2009: 1159, Hoad, 2000: 179, Wartburg, 1969: 709, 710, Ernout, 2001: 380). Согласно W. Wartburg, лат. silva forestis означает «лес вовне или внешний лес», а его вторая часть forestis, получившая впоследствии самостоятельное значение «лес» происходит от лат. foras (foris) «вне, снаружи» (Wartburg, 1969: 709, 710). Лексема лат. foris (foras) «вне, снаружи» происходит от и.е. $* d^{h}$ wer- «дверь, вход» (Ernout, 2001: 426) и означает: «за дверью». Лат. silva forestis - юридический термин, появившийся при Карле Великом и означающий внешние, «находящиеся за изгородью» некультивированные лесные зоны (в противовес огороженным парковым зонам; лат. parcus «внутри»), отведенные для охоты короля. W. Wartburg предложил и альтернативный вариант происхождения лат. forestis от лат. forum «суд»: тогда лат. silva forestis получает толкование, как «лес, находящийся в юрисдикции короля» (Wartburg, 1969: 710). E. Gamillscheg считает, что латинизированный термин forestis (foresta) «лес» произошел от франкской лексемы *forhist- «лес», являющейся дериватом протогерманских форм *furhō «ель, сосна» и *furhisa«хвойный лес» (Gamillscheg, 1969: 380). От этих форм происходят лексемы со значением «лес» в других германских языках: др.-в.-нем. forst, cp.-н.-нем. vorst; др.-сев. fýri, др.-англ. fyrhp и ср.-англ. firth (> англ. fir «ель»), frith (там же). Ассимиляция лексемы франк. *forhist «лес» с второй частью позднелатинского словосочетания silva forestis «внешнй лес» образовала латинизированный термин forestis (foresta) со значением «лес», который и был заимствован старофранцузским языком в варианте forest (Gamillscheg, 1969: 380, 381). В Европе 
суббореального периода (3300 - 400 гг. до н. э.) дубравы были оттеснены хвойными лесами, поэтому лексема и.-е. *perk ${ }^{w}$ - «дуб» приобрела в германских языках значение «ель, сосна», «хвойный лес» (Gamkrelidze, 1984: 616, 618). Ввиду этого обстоятельства протогерманские формы *furhō «ель, сосна», *furhisa- «хвойный лес» (Gamillscheg, 1969: 380), *furhwōn- «ель» (Kroonen, 2013: 161) являются производными от и.-е. *perk ${ }^{w}$ - «дуб». Сравним: нем. Föhre «ель, сосна», но и.е. *perk ${ }^{w}$ os «дуб» (Makovsky, 204: 141). И.-е. *perk-/*perk ${ }^{w}$ «дуб», но и.-е. *perk- «разрывать», «резать/гнуть», «горящие угли, гореть» (Makovsky, 1989: 83, 156).

Лексема русск. лес соотносится со значением «огонь». И.-е корень *as-/*esимеет значение «гореть» (Grigorova, 2008: 14). Внутрикорневое соотношение значений: и.-е. *es- «сечь»> «высекать огонь»> и.-е. *as- «огонь, гореть» (Makovsky, 1992: 45, 2007: 42). Переход значений: и.-е. *es- «высекать огонь»> и.-е. *leis- «рассекать» (плоть в процессе ритуальной борьбы) > ирл. lis, les «сакральная игра» > русск. лес, как место сакральной игры с имитацией борьбы и плясками у сакрального Центра - дерева (Makovsky, 2007: 50, 2004: 168).

Сравним еще значения «огонь» и «дерево». И.-е. *ar- «гореть», но хет. aras «дерево» (Makovsky, 1996: 135, 243). И.-е. *bher- «гореть», но и.-е. *bherg«дерево» и русск. береза (Makovsky, 1996: 136). И.-е.*ker- «гореть», но др.-англ. hyrst «лес, холмы», русск. корень, хворост (Makovsky, 1989: 86). И.-е. *gai-/*kai«гореть», но русск. диал. гай «лес» (Makovsky, 2002: 73). И.-е. *suel- «гореть», но лат. silva «лес», др.-англ. sylvan «лес» (Makovsky, 2002: 66). И.-е. *el- «огонь» (Makovsky, 1992: 22), но и.-е. *el- «дерево» и русск. ель (Makovsky, 1989: 171).

\section{3. Мировое древо является метафорой центра Мироздания.}

Божество рассекло Хаос на две равные половины, и появилась Середина символ вселенской Гармонии (Makovsky, 1999: 221). На Середине, в центре Мироздания «росло» Мировое древо и возносился к Небу его ствол (Makovsky, 1999: 400).

Сравним значения «дерево» и «середина, центр»: и.-е. *kerd- «середина», но и.е. *ker- «дерево», др.-англ. ceart «лес» и русск. середина; лат. arbor «дерево», но и.-ар. ardha- «середина»; и.-е. *medh- «середина» и др.-англ. midd «средний», но литов. medis «дерево»; ирл. fid, др.-англ. widu, англ. wood «лес, дерево», но литов. vidus «середина»; латыш, pusis «ель», но латыш. pus «половина, середина» (Makovsky, 1996: 135).

Реального объекта, который бы обозначало Мировое древо, нет, как и точного места его нахождения. Для древнего человека Мировое древо находилось в центре освоенного им мира, которым в первую очередь являлся его дом (Makovsky, 1989: 89, Makovsky, 1996: 265). Дом - укрытие от опасности. Переход значений: и.-е. *kewdh- «укрываться»> др.-англ. $h \bar{u} s$ «дом»> англ. house (Toporova, 1994: 35). Дом - «вторая кожа». Переход значений: и.-е. *cu/*cut- «покрывать» (> лат. cutis «кожа») > герм. *cuH-so, *hüsa- «дом»> др.англ. huss «дом»> англ. house (Pattridge, 2009: 1466, Kroonen, 2013: 260). Дом рукотворное убежище. Переход значений: и.-е. *dem- (*dam-, *dom-) «строить» $>$ лат. domus, герм. domos, санскр. dàmas «дом» (Pattridge, 2009: 860), о.-сл. domъ (Semenov, 2003: 263). И.-е *skeu- «резать/гнуть» > «плести, ткать»> др.-в.-нем. $h \bar{u} s$, др.-сакс. $h u s$, др.-англ. $h \bar{u} s$, др.-сев. hus «дом»> нем. haus «дом», поскольку в древности дома плелись из веток (Makovsky, 2004: 210). Др.-нем. и др.-англ. $h \bar{u} s$ «дом», англ. house и нем. haus «дом», но о.-сл. chyzъ и русск. хижина (Semenov, 2003: 534).

Дом, как центр Мироздания рассматривается в двух смыслах: как сакральное место ритуальной коммуникации с богами и как точка отсчета для ориентации в пространстве, освоенном человеком.

XLinguae, Volume 12, Issue 3, June 2019, ISSN 1337-8384, eISSN 2453-711X 
Дом - ближайшее место к огню как в прямом (очаг), так и в переносном смысле из-за «соседства» Огненной вертикали, родственной огню в очаге. В доме скрытно совершали таинство жертвоприношения богам, сжигая жертву на огне очага-алтаря. Дом был для древних людей не только жилищем, но и храмом сакральным местом ритуального общения с Божеством. Сравним значения. Др.англ. hūs «дом», но др.-англ. husel «жертвоприношение» (Makovsky, 1996: 51, 149). И.е. *ag- «огонь», но *ag- «сакральная игра» и жертвенное животное «козел» (Makovsky, 2012: 26). Др.-англ. и др.-нем. hüs «дом», но гот. gud-hūs «храм» (Pattridge, 2009: 1466). Лат. domus «дом», но лат. dominus «хозяин дома» и поздн. лат. Dominus - «Бог» (Pattridge, 2009: 860-861). Таинство сожжения жертвы на алтаре совершалось не только в жилых домах, но и в храмах, которые стояли в центре дворцовых комплексов, царских резиденций, городов. Лондон, упоминаемый в тексте оригинала, основан древними римлянами в своей провинции Британия в 50-60 гг. н.э. и имеет типичную схему застройки всех древнеримских городов. В Лондоне времен императора Клавдия была центральная площадь (форум) со зданием базилики (суд, администрация) и храмом (Perring, 1991:24), поэтому он имеет все признаки святого городацентра. Жилые дома-храмы с очагами-алтарями, культовые здания и социальные пространства, их включающие несут символику святости, сакрального Центра коммуникации человека с Божеством (Makovsky, 1996: 266).

Центр Мироздания является так же точкой отсчета для орентации в пространстве-времени Вселенной. В вертикальной проекции движение снизу вверх к Небу - «Добро», сверху вниз к Земле - «Зло» (Batueva, 2008: 12, 13, Makovsky, 1999: 39). В горизонтальной проекции движение к Центру - «Добро», от Центра - «Зло» (Grigorova, 2008: 8, Batueva, 2008: 15, Makovsky, 1999: 39). Все, находящееся внутри Вселенной под кроной Древа - Добро; вовне, на периферии - Зло (Makovsky, 1999: 246). Положение объекта относительно Центра, передающееся лексемами русск. рядом, возле (во зле) имеет смысл «Периферия», «Зло» (Batueva, 2008: 15).

4. Мировое древо является метафорой периферии Мироздания.

Пространство «своего» мира требовало отделения от «чужого» с помощью границы, метафорой котрой служило дерево, а точнее - боковые пределы его кроны. В реальной жизни граница устанавливалась изгородью, забором, деревянным колом. Все, что снаружи границы отделялось, а то, что внутри скреплялось.

Сравним значения «дерево» и «граница». И.-е. *mеi- «кол» и «скреплять», и.е.*mairjo- «скреплять», но др.-сев. теiðr «дерево, лес», латыш. теžs «лес», русск. межа, между и место (Makovsky, 2012: 240, 1989: 83, 129, Toporova, 1994: 57, 58). И.-е. *perk- «дуб, дерево», но др.-англ. furh «межа» (Makovsky, 1989: 156) и др.-англ. pearroc «огороженное место» (Makovsky, 1989: 83). И.е.*mereg- «граница, край», но др.-сев. mork «лес» (Toporova, 1994: 58). И.-е. *gher- «огораживать», но герм. *garda- «внутренний двор», англ. garden «сад», ст.-слав. градъ «укрепление, город, сад» (Toporova, 1994: 28, Kroonen, 2013: 169) Значение «дерево» соотносится со значениями «дальний», «внешний», «периферия» (Makovsky, 1996: 140, 141), отражая способность «своего» пространства к эксцентрическому расширению за счет достижения периферийной границы и выхода за ее пределы. Сравним. И.-е. *bhag- «дуб», но и «наружу, вовне» (Makovsky, 2012: 382). Англ. oak «дуб», но *bhak-, *bhok«периферия» (Grigorova, 2008: 12, Makovsky, 2002: 73). И.-е. *perk-«дуб, дерево», но осет. fars, ав. parsva «ребра, край» (Makovsky, 1989: 156), тох. А. parne «внешний», англ. far «далекий» (Makovsky, 2005: 197). И.-е. *ter-/*der«дерево», но и «далекий» (Makovsky, 2002: 67, 69). Др.-англ. widu, англ. wood 
«лес, дерево», но и.-е. *suet- «внешний, периферийный» (Makovsky, 2012: 104). И.-е *er- «ореховое дерево» (Makovsky, 2012: 136), но и «периферия, край» (Makovsky, 1999: 382). Хет. *aras- «дерево», но и.-е. *ar- «выступать вперед, находиться вдали» (Makovsky, 1996: 160). Др.-инд. vanah «дерево», но русское внешний (Makovsky, 1996: 141).

При выходе человека за границы «своего» мира соответствующий ему пространственно-временной континуум со всей информацией внутри сворачивается в точку, от которой возможно развертывание вовне к новой границе. Точка развертывания - залог будущего развития и свидетель прошлого, т.к. содержит все информационные коды о прошлых состояниях Вселенной (Tumanova, 2001: 30).

5. Мировое древо является метафорой Божества.

В древности люди поклонялись деревянным столбам-божествам - символам огненного столпа, принося им жертвоприношения (Makovsky, 1996: 66, 2005: 433). Поэтому значения «столб», «шест» соотносятся со значениями «огонь», «божество», «верх». Рассмотрим переход значений «дерево» и «огонь», «верх», «божество». И.-е. *ag- «дуб», но и «высокий» (Makovsky, 2012: 85) > «верх»> «божество». И.-е. *ter- «дерево», но перс. *tar- «верхушка, макушка» (Makovsky, 1999: 222) > «верх» > «божество». И.-е.*ker- «дерево», но и «верх» (Makovsky, 2012: 85) > «божество». И.-е. *ab- «дерево»>*kabh- «гореть»> *kabeiro- «божество»; англ. диал. caber «шест» > «огненный столб» > «божество» (Grigorova, 2008: 22). И.е. *keldos- «дерево, лес»> русск. кол (Makovsky, 2012: 85) > «столб огня» > «божество». Русск. лес < и.-е. *es- «сечь» $>$ «высекать огонь» > «гореть» (и.-е. *as-) > и.-е. *es- «быть, существовать» (Makovsky, 2007: 42) > «сущий»> и.-е. *oss «божество» (Makovsky, 1996: 49). Русск. лес < и.-е. *es/*as- «Гореть, вздыматься ввысь»> др.-сев. ass «шест», «божество» (Makovsky, 2012: 26, 1989: 83). И.е. *uеr- «гореть, вздыматься вверх», но англ. swir «столб» и русск. верх, ворожить > божество (Makovsky, 2012: 85). Сравним значения: и.-е. *ag-/ *bhag- «огонь», «дуб», но русск. бог (Makovsky, 2012: 132; 2002: 61); и.-е. *bhok-«гореть», но англ. oak «дуб» и русск. бог (Makovsky, 2002: 60).

В процессе сотворения Вселенной Божество рассекло и разъединило Хаос на две половины, а затем соединило части в соответствии с принципом Гармонии. «Рвать, сечь/гнуть, плести» - первичная семантическая диада, отождествляемая с действиями Творца (Makovsky, 2012: 15); подражание им - уподобление божеству. Сравним. И.-е *ak-/*ag- «дуб», но и «рассекать/гнуть»; и.-е. *ter-/*der «дерево», но и «рвать, рассекать/гнуть»; и.-е. *perk-/*perk ${ }^{w}$ - «дуб», но *perk/*per-ko «рассекать/гнуть»; и.-е. *еs- «рассекать», но русск. лес (Makovsky, 2007: $42)$; и.е. *ued-/*ueid- «рассекать/гнуть, соединять», но англ. wood «дерево, лес» (Makovsky, 2007: 44).

С понятием силы Божества связывалась Змея, которая по представлениям древних не умирала, а лишь меняла кожу и обновлялась. Рассмотрим переходы значений «дерево» - «змея» - «сила». И.-е *ak- /*ag- «дуб», но и.-е. *ag-, *nak«змея»; др.-инд. ahi, англ. snake, русск. гад «змея» (Makovsky, 2007: 41; 2005: $432)>$ «сила». И.-е. *perk- «дуб», но и.-е. *per- «змея» (Grigorova, 2008, 16), лат. vipera «гадюка» и нем. диал. Pier «змея» (Makovsky, 2007: 39) > «сила». И.-е. *ter-/*der «дерево», но и.-е.*ter- «змея» (Grigorova, 2008, 16) > «сила». Русск. лес< и.-е. *es- «сечь, рассекать», «существовать»> и.-е. es-mo «существовать»> англ. I am «я существую», но англ. диал. easse «червь, змея» (Grigorova, 2008: 14; Makovsky, 2007: 44) > «сила». Русск. лес< и.-е. *es- «сечь, рассекать»> англ. диал. easse «червь, змея»> «сила»> русск. диал. еслеть «сила, мощь» (Makovsky, 1996: 182). И.-е. *ar- «дерево»> бретонск. $\alpha e r$ «змея» » (Grigorova,

XLinguae, Volume 12, Issue 3, June 2019, ISSN 1337-8384, eISSN 2453-711X 
2008: 16) > «сила». И.-е. *ker- «дерево», но и «змея» (Grigorova, 2008: 16) > русск. червь и русск. диал. щур «червь» (Makovsky, 1996: 177) > «змея»> «сила».

Символом творящего Божества является звук (Makovsky, 1996: 49). Слово сила, божественная огненная энергия, символ движения Божества и его оружия - меча (Batueva, 2008: 11). Рассмотрим переходы значений «дерево» - «издавать звуки, говорить» - «сила Божества». И.-е *ag- «дуб», но и.-е. *ag- «издавать звуки, говорить» (Makovsky, 2007: 41; 2002: 64) > «сила». И.-е. *ter-/*der «дерево», но лит. tarti «говорить» (Grigorova, 2008: 18), лат fortis «сильный» (Vorfolomeeva, 2012: 11), кельт. trigio «музыка» (Makovsky, 1996: 161) > «сила, гармонияя». И.-е. *per-k- «дуб», но и.-е. *per- «говорить», русск. сnоp, англ. spear «копье» (Makovsky, 1996: 169) > «меч»> «сила». Англ. wood «дерево, лес» $<$ и.е. *ued-/*ueid- «соединять», но и «говорить, издавать звуки» (Makovsky, 2002: 71) > «сила».

6. Мировое древо является метафорой Божественного разума.

Мировое древо кодирует не только структуру пространства, но и функцию соединения ее элементов между собой. И.-е. *ue(i)- «соединять», но др.-сев. viðr «дерево»; и.-е. *mеi- «скреплять», но др.-исл. теіðr «дерево»: буквально «скрепляющее» (Toporova, 1994: 62). Иначе говоря, Мировое древо - путь между объектами Вселенной, по которому происходит движение. Человек гуманизирует пространство и его пути, помещая на них себя. Он получает первичную информацию об объекте через свои органы чувств и восприятие; в первую очередь - глаза и зрение. Сравним: и.-е. *ued-/*ueid «рассекать», но и.-е.

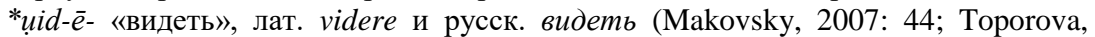
1994: 130). Сигнал, кодирующий информацию, поступает в мозг, запуская механизмы ее приема, переработки, оценки и хранения, являющиеся физиологическими процессами, на основе которых фунционируют мышление и память, строится интеллект - Разум - главный двигатель познания во Вселенной. Переход значений: и.-е. *ueid- «связывать», но и «знать»> др.-англ. witan «знать», англ. wit «разум» и русск. ведать (Makovsky, 1996: 352; Toporova, 1994: 130). Сравним: и.е. *ueid- «знать», но др.-англ. widu, англ. wood «лес, дерево», ирл. fid, др.-сев. viðr «дерево» (Makovsky, 1996: 400); и.е. *ued-men «разум», но русск. $у м$ (Kretova, 2012a: 353).

В древнегерманской модели мира движение мысли, как функции разума в процессе познания сочетает рост (вертикальная проекция Вселенной) и охват вширь (горизонтальная проекция Вселенной) (Toporova, 1994: 134). Мировое древо соотносится с пространством Вселенной в целом, поэтому соответствует универсальному пути познания Вселенной. Однако древние имели в виду главным образом его вертикальную составляющую - движение мысли. Если окинуть внутренним взором (русск. $y$-видеть, про-видец) всю временную ось пространственно-временного континуума от начала до конца Вселенной, то можно получить информацию о ней (русск. раз-ведать) в исчерпывающем объеме (Toporova, 1994: 130). В мифопоэтической традиции разум есть движение мысли, пронизывающей пространство и время, как в направлении будущего, так и в направлении прошлого; способность на основе их видения дать интегративную оценку явления в настоящем.

Сравним еще значения «лес, дерево» и «разум». И.-е. * $a(n) g$ - «дуб», но и.-е. *a(n)g-men «разум» и русск. ум (Makovsky, 1996: 268). И.-е. *ag- «дуб», но гот. aha «разум» (Makovsky, 2002: 72), тох. А aik «знать» (Makovsky, 2005: 432). И.е. *reto «лес» но лат. ratio «разум»; ирл. caill «лес», но ирл. ciall «разум»; литовск. medis «лес», но лат. meditare «размышлять» (Makovsky, 1996: 139; 268). Др.-инд. bodhi «дерево», но др.-инд. buddhi «разум» (Makovsky, 1996: 273). 
7. Мировое древо является метафорой фаллических (креативных) символов и действий.

Сравним значение «дерево» с фаллической символикой. И.-е *bhag- «дуб», но др.-инд. bhaga «vulva» (Makovsky, 2002: 79). Англ. wood, ирл. fid «дерево», но др.- русск. удъ «penis» (Makovsky, 2002: 79). Русск. лес (< и.-е *as-/*es«гореть»), но хет. hassis «мужчина»; русск. лес (< и.-е *es-/*kes- «рассекать»), но хет. has «родить» (Makovsky, 2007: 41; 45). Русск. лес (< и.-е *es- «быть»), но и.е. *is- сексуальная энергия, сила», «низ» (Makovsky, 2007: 44), русск. низ и церк.-слав. исто «testiculus» (Makovsky, 2007: 49). И.-е. *perk- «дуб», но и.-е. *perk-/*per- «разрывать» и лат. pario «рожать» (Makovsky, 1996: 365). И.-е *ter$/ * d e r$ «дерево», но и «быстро двигаться», «тереть/драть» > «соитие»; и.-е *ter/*der «дерево», но др.-англ. teors «penis», ирл. torr «матка», лит. turéti «иметь потомство» (Makovsky, 2007: 54; 1996: 138), русск. драть (Makovsky, 1996: 336), терзать и драка - «борьба, как часть акта творения-оплодо-творения».

Сравним еще. И.-е *ar- «дерево», но и «вздыматься вверх», «мужчина», «соитие» (Makovsky, 1996: 83). И.-е *ar- «дерево», но и осет. aryn «рожать», тох. А ar- «рожать, производить на свет» (Makovsky, 2002: 73). И.-е. *ker- «дерево», «творить, производить», «соитие», но тох. *ker- «половые органы», русск. крепкий (Makovsky, 1992: 60; 83; 1996: 135). И.-е. *ker- «дерево», но русск. кормить («поглощение пищи» = «соитие»), русск. диал. кур «penis» (Makovsky, 2002: 59). Др.-инд. vana- «дерево», но хет. uеn «соитие»; и.-е. *kük- «половые органы», но латышек. kuoka «дерево» (Makovsky, 2002: 79).

Атрибутивными характеристиками Бездны (женское начало) являются темнота и пустота, однако пустота - источник рождения. Сравним значения «дерево», «темнота», «пустота». И.-е. *ak- «дуб», но и «отверстие» (Makovsky, 1996: 38). И.-е. der-/*ter- «дерево», но и «отверстие», русск. дыра (там же). По энантиосемии в оппозиции «огонь, свет/темнота» и.-е. ter- «дерево» принимает значение «темный» (Makovsky, 2007: 40). И.-е. *der- «темный», но англ. dark «темный» (Makovsky, 2012: 27). И.-е. *perk-«дуб», но и.-е. *per- «отверстие» (Makovsky, 1996: 35) и «темный»: греч. лєркаvо «темный, пестрый» (Makovsky, 1989: 156). И.-е *ker- «дерево», но и «отверстие» (Makovsky, 1996: 39). Хет. aras «дерево», но и.-е. *ar- «отверстие» (Makovsky, 1996: 43; 44).

8. Мировое древо является метафорой потустороннего мира.

В кроне Мирового древа селились добрые и злые духи, души нерожденных и умерших людей, ожидающих своего времени вступления в цикл Жизни и Смерти » (Makovsky, 2007: 48; 1996: 165; 1999: 383; 400). Мировое древо объект потустороннего мира, пристанище для его добрых и злых сил.

Смерть и Жизнь рассматривались древними, как единый цикл: смерть - особое состояние жизни, а жизнь - путь к смерти. Переход от жизни к смерти представлялся древними, как путешествие, совершаемое по воде в направлении от Центра к Периферии (Makovsky, 2002: 70). Души мертвых переправлялись на лодках или кораблях в Нижний мир. Сравним. И.-е. *naus- «корабль», но и.-е. *nau- «смерть» (Makovsky, 1989: 138; 2005: 341). И.-е. *ug- «река», но хет. ug «смерть»; русск. ладья (для душ умерших), но др.-англ. lid «корабль» и liðan «умирать» (Makovsky, 1989: 138; 1996: 194).

Однако Смерть - путь к обновлению и возрождению: и.-е. *naи- «смерть», но и. e. *neuos- «новый»» (Makovsky, 1989: 138; 2005: 341). Движение к обновлению через водную среду выявляется при сравнении лексем и.-е. *sneu- «Гнуть, связывать» (о плетении вод), *sna- «вода», но англ. new «новый» и русск. новый (Makovsky, 1989: 137; 2005: 341). Из Нижнего мира души мертвых, переселившись в птиц (Makovsky, 2005: 106), летят к Мировому древу и поселяются в нем, ожидая нового цикла перехода от Смерти к Жизни »

XLinguae, Volume 12, Issue 3, June 2019, ISSN 1337-8384, eISSN 2453-711X 
(Makovsky, 2012: 184). Таким образом, Мировое древо осуществляет фунцию медиации при переходе от Смерти к Жизни.

Мировое древо является также образом всегда зеленого, цветущего, дающего плоды, а, значит, и молодого дерева. Вечно зеленая крона Древа и зеленый цвет - символы бесконечности обновления жизни в круге смерти и рождения (Toporova, 1994: 113). И.е. *gher- «сиять, гореть», но англ. green «зеленый» (Makovsky, 2002: 66). Рассмотрим переход значений «гореть, сиять, сверкать» и «зеленый». И.-е. *gher- «сиять, гореть» (Makovsky, 1989: 142), но и «питаться, поедать» (Makovsky, 1989: 137) и русск. жрать (Makovsky, 2002: 65) > «расти, цвести» > англ. green «зеленый». И.е. *'ghel- «гореть, сверкать» > лит. žélti (želiū), латв. zelt «расти, цвести» > русск. зеленый, зелень (Kroonen, 2013: 174).

Мифопоэтическая традиция древних германцев ориентирована на идею конца мира - распад связей, гибель Вселенной и богов. А обновление после кризиса Вселенной связывается с растительной символикой цветения, плодородия, изобилия и с возрождением вечно зеленого Мирового древа (Toporova, 1994: 113). Идеальное пространство - рай, где возобновится новый космогонический цикл и возродится Мировое древо, связывается с островом среди океана, изолированным и недосягаемым. Сравним: и.-е. * $a k^{w} a$ - «вода», но герм. *ahwo«остров» (Toporova, 1994: 108). Представление о рае, как о саде на легендарном острове Ирии среди океана существует и в славянской мифологии (Gerasimenko, 2015: 16).

Дерево, соединяя три космических мира, является медиатором коммуникаций между реальным миром людей и внеземными Верхним и Нижним мирами. Сравним значения «дерево» и «потусторонний мир». И.-е. *bh-ag- «дуб», но и.е. *bhak- «потусторонний мир, преисподняя»; и.-е. der-/*ter- «дерево», но арм. draht «потусторонний мир»; др.-инд. rohi «дерево», но лат. orcus «потусторонний мир»; русск. диал. рай, райник «лес, деревья», но русск. рай (Makovsky, 2002: 79). Хет. aras «лес», но и.-е. *ar- «потусторонний мир» (там же), др.-инд. naraka (и.-е *ar- «гореть» + *ak- «гореть») «потусторонний мир» (Makovsky, 2002: 67).

9. Мировое древо является метафорой старости и оставшегося позади.

Покидая лесное стойбище, древние люди оставляли стариков позади. Сравним. И.-е. *per-k- «дуб», но алб. plak «старик»; др.-сев. viðr «дерево», но лат. vetus «старый»; и.-е. *edhla- «хвойное дерево», но др.-англ. eald «старый» и англ. old «старый»; и.-е. *der- «дерево», но русск. древний; англ. treе «дерево», но и.-е. *stru- «старый»; и.-е. *ker- «дерево», но ирл. crionna «старый»; и.-е. *er-, *or«ореховое дерево», но и.-е. *ers- «задняя часть тела»; и.-е. *reto «лес, роща», но лат. retro «позади»; и.-е. *ar- «дерево», но русск. старый (Makovsky, 1996: 136; 156; 2005: 359). Вектор движения назад имеет отрицательную коннотацию опасности, болезней, несчастий (Batueva, 2008: 15).

Дендроцентрической парадигмой, ассоциированной с мифологемой Мирового древа, является группа лексем оригинального текста стихотворения со значением «дерево, лес»: англ. oak «дуб», tree «дерево», forest «лес», wood (wooded) «дерево, лес».

Рассмотрим мифологическую семантику лексем дендроцентрической парадигмы в тексте оригинала.

Лексема англ. oak «дуб» (и.-е. *a(n)g-, *ag- «дуб»+ *ak- «разрывать, гореть») несет в подтексте семантику Вселенной (и.-е. *a(n)g-«дуб», но авест. anghu«Вселенная»); Центра - Огненной вертикали (и.-е. *ag- «огонь», русск. огонь); Периферии (и.-е. *bhag- «наружу, вовне»; и.-е. *bhak-, *bh-ok- «периферия»); Божества (и.-е. *bhag-, *bhok- «дуб», но русск. бог; и.-е. *ag- «высокий» = верх; и.-е. *ag-/*ak- «разрывать/гнуть»= часть акта творения; и.-е. *ag-, *nak- «змея», др.-инд. ahi «змея» = сила; и.-е. *ag- «издавать звуки» = символ Бога-Творца); 
Божественного разума (и.-е. *ag- «дуб», но гот. aha «разум»); потустороннего мира (и.-е. *bhak-, *bhok- «потустронний мир»); фаллической символики (и.-е. *bhag- «дуб», но др.-инд. bhaga- «vulva»; пустоты, как источника рождения: и.е. *ak- «дуб», но и «отверстие»).

Лексема англ. tree «дерево» (< и.-е.*ter-/*der- «дерево») несет скрытую семантику Центра - Огненной вертикали (и.-е.*ter-/*der- «гореть»); Периферии (и.-е.*ter- «далекий»); уподобления Божеству (и.-е. .*ter-/*der- «разрывать, рассекать/гнуть» = часть акта творения; и.-е. *ter- «змея» и «сила»; и.-е. *ter«издавать звуки» = символ Бога-Творца); фаллических символов и действий (и.е. *ter- «тереть»> «соитие»; и.-е. *ter- «тереть», но др.-англ. teors «penis», ирл. torr «матка», лит. turéti «иметь потомство», русск. терзать - «бороться в процессе оплодо-творения»; темноты и пустоты, как источников рождения: и.-е. *ter- «темный», но и «отверстие, дыра»); потустороннего мира (и.-е. *ter-/*der«дерево», но арм. draht «потусторонний мир»); старого (англ. tree «дерево», но и.-е. *stru- «старый»). Англ. лексема tree «дерево» соотносится так же с Числом: и.-е. *ter- (*tris-) «три», олицетворяющим Гармонию трехчастной структуры Вселенной.

Лексема англ. forest «лес» (< и.-е. *perk-/*perk ${ }^{w}$ - «дуб») несет в подтексте семантику Вселенной (и.е. *perk- «дуб», но др.-англ. feorh «Вселенная»); Центра - Огненной вертикали (и.-е. *perk- «горящие угли»); Периферии (и.-е. *perk«дуб», но др.-англ. furh «межа»= «граница, край», осет. fars, ав. parsva «ребра, край»); уподобления Божеству (и.-е. *perk-/*per-ko «рассекать/гнуть» = часть акта творения; и.-е. *per- «змея»= сила; и.-е. *per- «издавать звуки», русск. cnop = символ Бога-Творца); фаллических символов (и.-е. *per- «разрывать», но лат. pario «рожать»); пустоты и темноты, как источников рождения (и.-е. *per«отверстие, дыра», и.-е. *perk- «темный»); старого: и.-е. *perk- «дуб», но алб. plak «старик».

Лексема англ. wood «дерево, лес» (< и.-е. *ue(i)d-/*ued- «соединять, связывать») несет скрытую семантику Центра - Огненной вертикали $(<$ и.-е. *ue(i)d-/*ued«гореть»); Центра Мироздания - Середины (др.-англ. widu, англ. wood «лес, дерево», но литов. vidus «середина»); Периферии (англ. wood «лес, дерево», но и.-е. *suet- «внешний, периферийный»); уподобления Божеству (и.е. *ued-/*ueid«рассекать/гнуть, соединять» = составные части акта творения); Божественного разума (и.-е. *ueid- «знать», но др.-англ. witan «знать», англ. wit «разум» и русск. ведать); фаллических символов (др.- русск. удъ «penis», но англ. wood, ирл. fid «дерево»); старого (др.-сев. viðr «дерево», но лат. vetus «старый»).

Анализ лексем текста оригинала, ассоциированных с мифологемой «Мировое древо» показывает, что их значения отождествляются главным образом с метафорами, символизирующими мужское, «вертикальное» начало Вселенной: Огненную вертикаль, Божество, Божественный разум и фаллос. Однако женское начало, ассоциированное с мифологемами «Женщина», «Вода», «Хаос», «Земля», «Низ», «Бездна», «Бессознательное», «Зло», «Смерть» (Makovsky, 1996: 34; 76; 146; Batueva: 13) также представлено в оригинальном тексте лексемами англ. mother «мать», girl «девочка, девушка», deер «бездна».

Лексема англ. mother «мать» имеет метафорическое значение «Вода» (ср.: и.-е. *mad- «вода, жидкость»; др.-англ. modor «вода»), которая является и частью первичного бесструктурного Хаоса, и божестенным первотворением с женским началом, окружающим Вселенную по периферии (Makovsky, 1996: 227; 2005: 326). Понятие Матери связывалось древними также с последним, синим цветовым кругом горящего огня, олицетворяющим потусторонний мир (ср. и.-е. *madhro- «синий») и с Землей (ср.: др.-в.-нем. mot «земля»; латышск. meita «девочка») (Makovsky, 2005: 326). Земля же ассоциировалась с могилой, поглощающей как семя (зерно), так и тела мертвецов: тох. A pāts «земля», но

XLinguae, Volume 12, Issue 3, June 2019, ISSN 1337-8384, eISSN 2453-711X 
и.е. *pad- «есть, съедать»; др.-англ. hruse «земля», но и.-е *gher- «есть, съедать» (там же). С могилой, поглощающей (буквально: «съедающей») фаллос в процессе соития отождествлялись значения «мать», «женщина». Сравним: др.англ. wip «женщина», но хет. wappи «могила» (там же). Лексемы англ. mother «мать» и русск. (устар.) матерь можно истолковать, как сложение корней: гот. matjan «есть, съедать» + др.-англ. teors «фаллос» = «поглощающая фаллос» (там же). Однако, и зерно в земле, и сперма в вагине «умирают», давая всходы новой жизни (Makovsky, 1999: 229). Плодородие Земли и женщины-Матери метафора бесконечного круга Смерти и Жизни. Лексемы англ. mother «мать» и русск. (устар.) матерь несут в подтексте семантику Воды, потустороннего мира, фаллических символов плодородия и единства жизни и смерти.

Значения «женщина», «девушка, девочка» символизировались древними значением «женский половой орган», а последний ассоциировался с горлом или глоткой, поглощающими фаллос и сперму (Makovsky, 2012: 118). Сравним: ср.англ. wesen, англ. диал. weasond «горло, глотка» (< и.-е. *ues- «глотать, съедать»), но осет. woes «женщина»; нем. Kehle «горло, гортань», но тох. А. kuli «женщина»; др.-сев. prudr «женщина», но англ. throat «горло, глотка» (Makovsky, 2005: 221; 222; 2004: 258). М.М. Маковский полагает, что англ. girl «девочка, девушка» может соотноситься с др.-инд. gir «глотать, заглатывать» и русск. жерло, горло (Makovsky, 2005: 221), неся фаллическую женскую символику, хотя некоторые исследователи считают, что эта лексема имеет кельтские (ср.: ирл. caile, др.-ирл. cale «девочка, девушка») или германские корни (ср.: нижне-герм. goere «молодой человек независимо от пола») (Pattridge, 2009: 1280). Сравним еще: и.-е. *dhei- «сосать» (грудь, молоко), но русск. дева, девочка, девчушка; дословно: «дитя, вскормленное молоком» (Makovsky, 1992: 52; 1989: 80).

Образ Бездны передается лексемой англ. dеер «бездна». Бездна - креативное женское начало, ассоциировавшееся с зияющим отверстием, полостью или сосудом, которое является местом, откуда все происходит, и куда все возвращается, включая богов и Вселенную (Makovsky, 2005: 167). Сравним: и.е. *ghei- «зиять, бездна», но др.-англ. geap «бездна» и gad «пустота, зияние, дыра» (Makovsky, 1992: 35); др.-англ. ginian, др.-сев. gina, нем. Gähnen «зиять, зевать» и русск. зиять (Makovsky, 2004: 156). Неотъемлемыми характеристиками Бездны являются темнота, пустота и глубина. Пустота символ будущего рождения, отражающий ее женское начало: др.-сев. tomr «пустой», но тох. А täm «рожать» (Makovsky, 2007: 52). Сравним значения «глубокий» и «бездна»: и.е. *dheubh-/*dhubh- «глубокий», но др.-англ. deop, др.сакс. diop, др.-сев. djupr, англ. deep, литовск. dubus «глубина, бездна» (Makovsky, 2005: 166; 167). Лексема англ. dеер «бездна» содержит в подтексте образ непостижимой глубины. Рассмотрим так же переход значений: и.е. *dheubh-/*dhubh- «глубокий»> и.-е. *dhub-no- «основание, дно» > русск. дно (Makovsky, 1999: 102; 2005: 166) и без-дна.

Мифологема «Птица» ассоциировалась древними с Периферией по отношению к Центру - Мировому древу и стремлением возвратиться к нему, несмотря на любые преграды (Makovsky, 1996: 107, 109). Лексему англ. bird «птица» можно истолковать, как сложение корней: и.-е.*bher- «быстро двигаться» + и.-е. *di$/ * d a u$ - «гореть» (Makovsky, 1999: 61; 62). Птица - вместилище душ умерших и неродившихся людей (Makovsky, 2005: 106). Переход значений: англ. bird «птица»> англ. breathe «дышать»> «душа» (Makovsky, 2012: 49; 2005:106). Лексема англ. bird «птица» несет в подтексте семантику огня, как символа души (Makovsky, 1999: 383; 400; 2005: 106; 107). Сравним: и.-е. *pet-no «край, сторона, периферия», но русск. птица (Makovsky, 2012: 184).

Англ. лексема lichen «лишайник» является метафорой сексуальной потенции, жизненной энергии, как основы жизнеспособности и процветания рода. Англ. 
lichen «лишайник» соотносится с нем. Geschlecht «род» (Makovsky, 1992: 85). Лексема нем. Geschlecht «род» так же соотносится с исл. lokur «penis», корнийск. lygyon «гениталии» (< и.-е. *lek-/*sleg- «высекать, бить»), так как рождение ассоциировалось древними с трением дерева о дерево или с борьбой аналогом первичного сакрального полового акта Божества с Хаосом, в результате которого появилась Вселенная (Makovsky, 2004: 182). Переходы значений «лишайник» и «род»: англ. lichen «лишайник»: симбиоз гриба и водоросли > «гриб или нарост в виде гриба» > «низ» > «сексуальная энергия» > «половые органы» > «соитие»> «рожать»> «род» (Makovsky, 1992: 45; 2007: 41); или: англ. lichen «лишайник» (< и.-е. *leigh- «лизать»> русск. лизать (Pattridge, 2009: 1772)) > «язык» > фаллическая символика: язык, как орган оплодотворения > «penis» > «сексуальная сила» > «соитие > «рожать» > «род».

Значение лексемы англ. hоте «дома, домой» имеет отношение к мифологеме «Середина» и освоению человеком пространства Периферии. Вокруг дома человека - «Середины», как точки отсчета в пространстве формировались другие ограниченные (в примитивном понимании - огороженные) территории, освоенные и обжитые им. Для древнего человека к «своим» территориям кроме дома относились двор для пользования членами семьи и домочадцами; поселение - группа домов, где жили члены одного рода. Позже к ним присоединились деревня, где проживали соплеменники; округа, город и страна, где на общей территории селились члены одного социума. «Свое» пространство ассоциировалось с состоянием покоя, лежания. Переход значений: и.-е. *kei$/ * k^{(h)} e i-$ «лежать»> и.-е. $* k^{(h)}$ óym-/*kei-mo- «поселение»> герм. *haima«поселение»> др.-англ. hām «поселение» (Toporova, 1994: 35; Kroonen, 2013: 201). Др.-англ. hām имеет также значения «дом, жилище», «дом с землей», «поместье», «группа жилищ» (Pattridge, 2009: 1445). Лексема ср.-англ. ham имеет те же значения, но и дополнена новыми: «место рождения или проживания», «страна» (Hoad, 2000: 219). Весь спектр рассмотренных значений сохранился в лексеме англ. hоте «дома, домой» (Нoad, 2000: 219). В социальном пространстве идея полагания, покоя и принадлежности к «своему» приобрела дополнительную коннотацию неизменности и прочности, личной привязанности. И.-е. * $k^{(h)} e i-w o-\left(<* k e i-/ * k^{(h)} e i-\right.$ «лежать») означает «этот, здесь, свой», а и.-е. $k^{(h)} e i-w-r$ - «принадлежащий своим, полноправный член общества» (Toporova, 1994: 98; 99; Kroonen, 2013: 227). Санскр. śeva- «любимый, дорогой» (Kroonen, 2013: 227). Др.-сев. hýrr «свой, член семьи», «милый, приятный» (Toporova, 1994: 98; 99). Переходы значений: и.-е. * $k^{(h)} e i$-wo- «этот, здесь, свой» $>$ герм. *hīwōn- «семейная пара, семья»> др.-англ. hīwan «семейная пара, член семьи» (Kroonen, 2013: 227); и.-е. *keị-/*k(h) ei- «лежать» > лат. cìvis «Горожанин», cìvitās «Город, государство» > англ. city «город», citizen «горожанин», «гражданин» (Pattridge, 2009: 519; Hoad, 2000: 78; Kroonen, 2013: 227; Ernout, 2001: 124); и.-е. * $k^{(h)}$ óym-/*kei-mo- «поселение», но лит. šeimà «домочадцы, семья», прусск. seimins «семья» и русск. семья (Toporova, 1994: 35; Ernout, 2001: 124). Учитывая географические и социальные аспекты можно заключить, что лексема англ. hоте «дома, домой» означает освоенную людьми, ограниченную территорию совместного проживания размерами от собственного дома до страны, на которой живут полноправные члены одного социума. В русском языке с лексемой англ. hоте «дома, домой» частично совпадают по смыслу лексемы дом, семья, родина, отечество и словосочетания родимые края, знакомые места.

\section{Обсуждение}

Стихотворение Д. Дрейкотт «Из Италии - к Господу» посвящено повсеместному истреблению лесов, как личной проблеме героя стихотворения,

XLinguae, Volume 12, Issue 3, June 2019, ISSN 1337-8384, eISSN 2453-711X 
рассматриваемой через призму общечеловеческой и вселенской значимости этой экологической катастрофы.

Текст произведения имеет мифологический подтекст, связаный с семантикой утраты Мирового древа, последствия которой с позиции мифологичесого мышления представлены ниже.

1. Утрата Мирового древа, как символа Вселенной - исчезновение материи, пространства; пространственно-временного континуума.

2. Утрата Мирового древа, как символа Огненной вертикали - распад трехчастной структуры пространства Вселенной; исчезновение верха и низа, а с ним - тотальная дезинтеграция взаимодействий мужского и женского начала.

3. Утрата Мирового древа, как символа Центра Мироздания - утрата Середины - божественного принципа вселенской Гармонии. С одной стороны это утрата символа святости, сакрального Центра, как канала коммуникации людей с Божеством. С другой стороны, это утрата Центра, как точки отсчета в пространстве «своего» мира человека: дома вместе с его социумом - семьей.

4. Утрата Мирового древа, как символа Периферии освоенного человеком мира - утрата границ «своих» пространств за пределами дома - двора, поселения, деревни, округи, города, страны вместе с членами соотвествующих им социумов: родных, близких, односельчан, земляков, членов одной народности, этноса, нации; граждан одной страны. Утрата границ освоенного невозможность создать точку развертывания для его расширения.

5. Утрата Мирового древа, как символа Божества - утрата его созидающей (творец), регламентирущей (закон), регулирующей (ритуал), карающей (судья), защитной (спаситель, хранитель) функции.

6. Утрата Мирового древа, как символа Божественного разума - исчезновение Пути - функции установления когнитивных связей между человеком (субъектом) и Вселенной: объектом познания; утрата интеллекта и способности к предвидению, как интеграции памяти о прошлом и логических операций вычисления устойчивых тенденций развития будущего.

7. Утрата Мирового древа, как метафоры фаллических символов и действий потеря мужского и женского креативного начала, способности к продолжению рода.

8. Утрата Мирового древа, как метафоры потустороннего мира - исчезновение медиатора перехода от Смерти к Жизни; утрата способности всего живого к циклическому обновлению и возрождению после гибели Вселенной на этапе ее перехода Небытия к Бытию.

9. Утрата Мирового древа, как метафоры старости и оставшегося позади утрата памяти и опыта прошлых поколений, преемственности между поколениями.

Обратимся к тексту перевода (таблица №1B). Рассмотрим мифологическую семантику лексем дендроцентрической парадигмы в тексте перевода.

Известно, что и.-е. праформы *ag-, *perk- со значением «дуб» не стали (или перестали) употребляться в славянских языках в этом смысле, вероятно из соображений табу, а этимология заменивших их др.-русск. дубъ и русск. дуб не вполне ясна (Gamkrelidze, 1984: 615; 618). М.М. Маковский соотносит русск. лексемы дуб, дубрава с литов. dumbrus «сырой», dumbre «слякоть», латыш. dumbrs «болото» (Makovsky, 1989: 64). При переводе на русский язык лексема русск. дуб, заменившая лексему англ. oak «дуб» не поддерживает мифологический подтекст оригинального текста, и он теряется.

При переводе на русский язык лексема англ. tree «дерево» заменена на лексему русск. дерево, которая является производным от общего и.-е корня *ter-/*der«дерево», а потому полностью сохраняет семантику: Центра - Огненной вертикали (и.-е. *ter-/*der- «гореть»); Периферии (и.-е.*ter- «далекий»); уподобления Божеству (и.-е. .*ter-/*der- «разрывать, рассекать/гнуть» $=$ часть 
акта творения; и.-е. *ter- «змея» и «сила Божества»; и.-е. *ter- «издавать звуки» = символ Бога-Творца); фаллических символов и действий (русск. драть = «соитие»; и.-е. .*ter- дpamь, но драка, как часть сакральной игры; темноты и пустоты, как источника рождения (и.-е. *der- «отверстие», русск. дыра; и.-е. *der- «темный», но англ. dark «темный»); потустороннего мира (и.-е. *ter-/*der«дерево», но арм. draht «потусторонний мир»); старого (русск. древний); гармонии трехчастности Вселенной (и.-е. *ter- «три»).

При переводе на русский язык лексемы англ. forest «лес» и англ. wood «дерево, лес» заменены на лекему русск. лес, несущую в подтексте семантику: Центра Огненной вертикали (и.-е. *as-/*es- «высекать огонь, гореть»); уподобления Божеству (и.-е. *es-/*as- «гореть, вздыматься ввысь», но др.-исл. ass «шест», «божество»; и.-е. *es- «высекать огонь»> «гореть» (и.-е. *as-) > и.-е. *es- «быть, существовать» > «сущий»> и.-е. *oss- «божество»; и.-е. *es- «рассекать»= часть акта творения; и.-е. *es- «сечь», и.-е. *leis «рассекать» (плоть) = уподобление божеству»; и.-е. *es- «существовать»> и.-е. *es-то «существовать» > англ. I am «я существую», но англ. диал. easse «червь, змея» = «сила»); фаллических символов (русск. лес, но хет. hassis «мужчина», хет. has «родить»; и.-е. *isсексуальная энергия, сила», «низ», русск. низ и церк.-слав. исто «testiculus»).

Итак, в процессе перевода с английского языка на русский количество лексем, ассоциированных с мифологемой «Мировое древо» сокращается с четырех до двух. Лексемы русск. дерево, лес сохраняют в подтексте семантику Огненной вертикали, Периферии, Потустороннего мира, Божества, старого и древнего; фаллическую символику, но утрачивают метафорические значения «Вселенная», «Середина, как символ святости и точка отсчета», «Божественный разум».

В тексте оригинала присутствуют еще две метафоры, относящиеся к Мировому древу, как к родовому древу, отождествляемому с родом. Лексема англ. lichen «лишайник» несет в подтексте семантику сексуальной потенции и плодородия, необходимых для продолжения рода, поэтому при переводе на русский язык лексема англ. lichen «лишайник» заменена лексемой русск. род. Лексема англ. linnet «коноплянка» (< ст.-фр. и фр. lin «лен»< лат. linnum «лен») означает птицу, питающуюся семенами льна (Pattridge, 2009: 1794). Вероятно, лексема англ. linnet «коноплянка» также несет в подтексте фаллическую символику, относящуюся к продолжению рода. Возможный переход значений: «коноплянка» > «семена льна» > «семя»> «сперма» > «соитие > «рожать» $>$ «потомство»> «род». При переводе на русский язык лексема англ. linnet «коноплянка» заменена лексемой русск. семя > «потомство, род».

Изучим метафорические значения лексем, ассоциированных с женским началом Вселенной в тексте перевода.

При переводе на русский язык лексема англ. girl «девочка, девушка» заменена на лексему русск. девчушка: исходная фаллическая символика оригинала утрачивается и появляется новый смысл: дева; дитя, вскормеленное молоком. При переводе на русский язык лексема англ. mother «мать» заменена на лексему от общих и.-е корней: русск. (устар.) матерь, сохраняющую в подтексте семантику Воды, потустороннего мира, фаллическую символику плодородия и единства жизни и смерти. При переводе на русский язык лексема англ. deep «бездна» заменена на лексему от общего и.-е. корня руск. бездна, сохраняющую семантику безмерной глубины.

При переводе на русский язык лексемы англ. bird «птица» заменена лексемой русск. птица с метафорическим значением «край, периферия» и семантикой возвращения к Центру в подтексте. Образ «летучего огня», несущего душу умершего человека утрачивается, но появляется семантика стремления к Середине.

XLinguae, Volume 12, Issue 3, June 2019, ISSN 1337-8384, eISSN 2453-711X 
При переводе на русский язык лексема англ. home «дома, домой» заменена на лексему от общего и.-е корня русск. семья, являющуюся гипонимом и в социальном, и в географическом аспекте, что потребовало введения в текст перевода русских лексем и словосочетаний с частично совпадающими значениями: очаг (жилище, дом), знакомые края, свой, любили, близкие для более адекватной передачи смыслов текста оригинала.

Рассмотрим подробнее приемы, позволяющие восстановить в тексте перевода утраченные значения «Божественный разум», «Вселенная» и «Центр Мироздания, Середина».

В отличие от английского языка (англ. oak «дуб», но и гот. aha «разум» (< и.-е. *ag- «дуб»); англ. wood «дерево, лес», но англ. wit «разум» (< и.-е. *ueid«связывать, знать»), в русском языке нет лексем со значениями «дерево» и «лес», несуших в подтексте семантику Божественного разума. Однако в

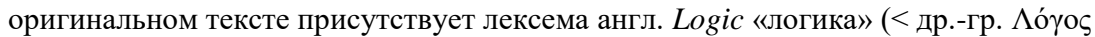
«рассуждение, мысль, разум»), также несущая семантику интеллекта Божества Логоса (Pattridge, 2009: 1751). При переводе лексема англ. Logic «логика» заменена на лексему русск. разум («...mom, что с миром не вразрез...»), компенсирующую утрату семантики Мирового (божественного) разума через его «дендрологические» метафоры.

Символ наряду с лексикой участвует в формировании целостного образа. Если лексическая состаляющая текста перевода не представляет адекватно смыслы оригинала, то усиливается семантическая нагрузка на его символическую составляющую или в текст перевода вводится словесный эквивалент символа. Например, в тексте оригинала лексема англ. oak «дуб» (и.-е. *a(n)g-«дуб», но авест. anghu- «Вселенная») является метафорой Вселенной, однако этот смысл отсутствует в русском языке. Одним из символов Вселенной является Змея (Makovsky, 1992: 82; 2005: 432). Семантику Змеи несут как лексемы текста оригинала англ. oak «дуб», tree «дерево», forest «лес», wood «дерево, лес», так и лексемы переводного текста русск. дерево и лес. Следовательно, семантика образа Вселенной передана из текста оригинала в текст перевода через ее символ - Змею. Еще пример: круг (проекция сферы) с точкой посередине, передающей положение Мировой оси сферы-Вселенной и Мирового древа на «круге земном» является символом Вселенной (Toporova, 1994: 22; Tumanova, 2001: 28; 29). Для передачи семантики значения «Вселенная» в текст перевода введен словесный эквивалент символа - лексема русск. кругом (т.е. вокруг точки-проекции «Я» во Вселенной), которой нет в оригинале.

Центр Мироздания находится на пересечении вертикальной проекции Вселенной (мужского начала) с ее горизонтальной проекцией (женским началом); это пересечение формирует сложный метафорический образ креста символа «Середины». Вертикальный компонент креста в текстах оригинала и перевода в рамках «дендрологических» метафор представлен семантикой Огненной вертикали, Божества и фаллической символикой, а его горизонтальный компонент - лексемами со значениями «мать» (англ. mother «мать» и русск. (устар.) матерь) и «бездна» (англ. deер «бездна» и русск. бездна). Следовательно, семантика Центра мироздания передается в обоих текстах через его символ - крест, придающий «Середине» дополнительную коннотацию объемности, развернутости в пространстве и времени.

«Середина» отождествляется с домом-храмом, который вместе с другими культовыми пространствами несет функцию символа святости. В тексте оригинала символы святости - «святой город» Лондон и невербализованная метафора «Середины»: дом-храм, ибо словосочетание англ. living room «гостиная» подразумевает наличие жилого дома с огнем для жертвоприношений в очаге, которому тропны Огненная вертикаль и осевая часть Мирового древа ствол. В текст перевода введена русск. лексема дом, как метафора «Середины»; 
разделены пространства дома и гостиной - центрального помещения с очагомалтарем, где вместе собираются члены рода для совершения таинства жертвопришения огню.

Территории, освоенные каждым человеком - это индивидуальное пространство «своего» под кроной Мирового древа; персональные Средний мир и пределы Вселенной. Средний мир - невербализованная метафора «Середины» в тексте оргинала. В антропоморфной модели Вселенной слова, обозначащие живот и его содержимое («утроба», «нутро», «кишки», «внутренности») имеют значение «огонь», «внутри», «середина» (Makovsky, 1999: 159). В текст перевода введено словосочетание «лесная утроба», чтобы обозначить пространство Среднего мира под кроной Мирового древа, а затем внутрь него помещены, в порядке иерархии, выявленные при анализе текста оригинала «свои» территории героя стихотворения: Лондон, дом и гостиная.

Семантику «Середины» несет также лексема шум (шумит), введенная в текст перевода: и.-е. *sem- «середина, половина», но русск. шум (Makovsky, 1996: 170). Образ шумяшей листвы на кронах деревьев передает идею сакральности происходящего в художественном пространстве текста перевода.

Помимо лексем русск. дом, шум и словосочетания лесная утроба, несущих в подтексте семантику «Середины», в текст перевода введено также словосиноним: русск. посереди.

Актуализация символики креста; введение в текст перевода лексем русск. посереди, дом, шум (шумит) и словосочетания лесная утроба («внутри, в середине леса») позволяют восполнить утраченный смысл «Середины»; выстроить художественное пространство, как мифологическое, что облегчает его распознавание на уровне восприятия при чтении.

Проанализируем далее мифологическую фабулу оригинального текста и особенности ее интерпретации в тексте перевода.

В первой строфе автор вводит в повествование героя произведения, который, находясь в состоянии молитвенного экстаза (из заглавия следует, что стихотворение - молитва) силой мысли вышел на временную ось Вселенной через временной портал - стекло распахнутой дверцы книжного шкафа. Физическое тело героя находится на временном отрезке, относящемся к 21 веку (“... a century has passed...”), однако его сознание, двигаясь по вертикальному Пути, проторенному к Божеству поколениями шаманов, жрецов и прорицателей, совершает переход в прошлое. Герой попадает в пространственно-временную точку, относящуюся к периоду детства своей матери: гостиную комнату лондонского дома начала 20 века. Перед ним открывается фантасмагорическая картина дремучего леса, растущего прямо в гостиной, которая вплотную подводит воображение читателя к главному мифопоэтическому образу произведения - Мировому древу.

Положение матери героя не определено четко в тексте оригинала, но очевидно, что оно должно быть совмещено с «Серединой», поскольку позиции, обозначаемые лексемами со значением «рядом» или «возле» отождествляются с Периферией, что не согласуется ни с логикой развития сюжета, ни с мифологической фабулой произведения. Мать героя в тексте перевода находится в центре комнаты родового дома-храма в святом городе Лондоне под сенью Мирового древа: на «Середине», которая является и символом святости, и индивидуальной точкой отсчета пространства-времени ее жизни. Сравним значения: и.е. *perk-«дуб», но др.-англ. feorh «душа, жизнь» (Makovsky, 2007: 48) и тохар. В preke «время» (Makovsky, 1989: 64). Весьма вероятно, что шестнадцать дубов, растущие в гостиной кодируют год рождения матери героя: 1916. Для героя лондонское «семейное гнездо», очевидно, также является 
символом святости и индивидуальной точкой отсчета жизненного пространствавремени.

Под маской игры в кругосветное путешествие читателю представлен виток цикла Жизни и Смерти матери героя, а символическое движение ее души по траектории, предначертанной Божеством, то отдаляется (Жизнь $\rightarrow$ Смерть), то приближается (Смерть $\rightarrow$ Жизнь) к индивидуальной точке отсчета - Мировому древу в лондонском доме семьи. Хотя дом в Лондоне является истинной точкой отсчета в пространстве ее воображаемого кругосветного путешествия (Лондон $(=$ «Центр») $\rightarrow$ Италия $\rightarrow$ Итака $\rightarrow$ Измаил $\rightarrow$ Япония $\rightarrow$ Австралия, где произошла встреча с парусником Джеймса Кука (= «Периферия») $\rightarrow$ движение к Центру, Италия), однако, если судить только по географическим названиям со страниц «Британники», то это путешествие и началось, и завершилось в Италии. Очевидно, первая часть названия стихотворения «Из Италии - к Господу» отражает формальное содержание сюжета произведения, а вторая - его глубинную, мифологическую суть.

По воде, на виртуальном корабле умершая мать героя в образе девочки, а точнее - ее душа совершает путешествие на Периферию, чтобы попасть в загробный мир. Движение от Центра в направлении Периферии - «Зло», поэтому в поверхностном семантическом слое текста второй строфы закономерно возникает дискурс о природе Зла с перечислением представителей основных религиозно-мистических учений прошлого - евреев с их Каббалой, Иеговой и Христом; индийского поэта-мистика и философа-гуманиста Кабира, которые дополнены словами-триггерами, ассоциирующимися с исламом (Кабул и каффир).

Необходимостью возвращения к Мировому древу для завершения этапа Смерти и совершения перехода к новому витку Жизни обусловлено появление в семантическом пространстве текста мифологемы «Птица». Душой матери движет надежда (она озвучена устами героя), что при воссоединении с Мировым Древом, как древом жизни сексуальная энергия, идущая «снизу», от корней рода вытолкнет ее в новый жизненный цикл (идея - толчок, удар, как в обрядах перехода). Но этим надеждам не суждено сбыться: по всей планете уничтожаются физические носители идеи Мирового древа - деревья и лес; теряется прочная связь человека и его культуры с природой, что делает возрождение невозможным.

Текст третьей строфы, описывающий современную экологическую катастрофу содержит картину Апокалипсиса - распада всех связей и гибели Вселенной. Переход значений: англ. gold «золото» и yellow «желтый < и.-е. *ghel-/*ghel-dh/*ghel-edh- «гореть, сиять» > «место огня» > русск. желудок > «внутренности»> «Центр, как место сосредоточения огня и души» > «душа» (Makovsky, 1999: 154; 2004: 192). Золото, как и недра в целом - «душа» земли: русск. вынуть душу - «убить». Атрибутивный признак земли - плодородие (Makovsky, 1999: 229), поэтому «убить» землю - сделать ее бесплодной.

Герой, находясь на временной оси Вселенной, перемещается по ней из прошлого в будущее и видит, как из темного жерла Бездны на острове, находящемся где-то вовне, среди океана рождаются новые Вселенная, Время и Мировое древо. Под его сенью даровано место, как самому герою, так и общечеловеческой надежде на обновление и возрождение. В тексте оригинала присутствует невербализованная метафора «будущее», которая вербализована в тексте перевода введением лексемы русск. грядущее, чтобы донести до сознания читателя глубинную семантику мифологического подтекста и связанные с ней авторские идеи оптимизма и гуманизма. 


\section{Заключение}

В процессе перевода стихотоворения Д. Дрейкотт «Из Италии - к Господу» использование ЛСУИЯ позволило определить доминирующую мифологему «Мировое древо» и создать перечень ее метафорических значений; выявить и сравнить метафорические значения мифологемы «Мировое древо» в группах ассоциированной лексики текстов оригинала и перевода; обнаружить утраченные значения мифологемы «Мировое древо» в тексте перевода и на основании точных данных выработать приемы их семантического восполнения; определить метафорические значения и место прочих мифологем в мифологической фабуле произведения; акцентировать внимание не на интепретации сюжета стихотворения, а на изучении его глубинного мифологического содержания. Предложенный алгоритм действий позволяет в процессе перевода использовать ЛСУИЯ, как эффективный инструмент комплексной оценки мифологем со сравнением их значений в неблизкородственных английском и русском языках. Комплексная оценка мифологем в поэтических произведениях с мифологическим подтекстом способствует более адекватной передаче мифологической семантики и индивидуально-авторских смыслов, что позволяет рекомендовать использование ЛСУИЯ для практического применения в рамках перевода мифопоэтических текстов.

\section{Bibliographical references}

BATUEVA, A.A. 2008. Mythologem of good and evil in Indo-European languages: author's abstract of candidate's thesis. Moscow.

DRAYCOTT, J. 2016. The Occupant. Manchester: Carcanet Press. ISBN 978-1-78410300-2

ERNOUT, A. - MEILLET, A. 2001. Dictionnaire Etymologique De La Langue Latine: Histoire Des Mots. 4 edizione. Klincksieck. ISBN 978-2252033593

GAMILLSCHEG, E. 1969. Etymologisches Wörterbuch der französischen Sprache. Heidelberg: Carl Winter Universitätsverlag. ISBN 978-3-825-305017

GAMKRELIDZE, T.V. - IVANOV, V.V. 1984. Indo-European language and IndoEuropeans. Reconstruction and historical-typological analysis of proto-language and protoculture. V.2. Tbilisi: Publishing house of Tbilisi University. ISBN 5-45846-7280

GERASIMENKO, I.A. - DMITRIEV, Yu.L. 2015. The image of the world tree through the prism of Russian linguoculture. In: RUDN journal of Russian and foreign languages research and teaching, vol. 4, pp. 16-22. ISSN 2313-2264

GRIGOROVA, E.Yu. 2008. Transformations of the Indo-European root in the light of the history of culture: lexico-etymological and linguocultural research: author's abstract of candidate's thesis. Moscow: Publishing house of Voenny universitet.

HOAD, T.F. 2000. Oxford Concise Dictionary of English Etymology. New York: Oxford University Press. ISBN 978-0-192-83098-2

KRETOVA, L.N. 2012. The anthropocentric mythopoetic paradigm in the poem «Forward» by N.A. Zabolotsky and features of translation of the poem into English. In: Vestnik Novosibirskogo gosudarstvennogo pedagogicheskogo universiteta, vol. 5 (9), pp. 115-122. ISSN 2226-3365

KRETOVA, L.N. 2012. Mythological component of the image of water in the early lyrics of N. Zabolotsky and the problem of translating a poetic text into English. In: Vestnik Novosibirskogo gosudarstvennogo pedagogicheskogo universiteta, vol. 6 (16), pp. 140-147. ISSN 2226-3365

KROONEN, G. 2013. Leiden Indo-European Etymological Dictionary Series: Etymological Dictionary of Proto-Germanic. Leiden, Boston: Brill. ISBN 978-90-04-183407

XLinguae, Volume 12, Issue 3, June 2019, ISSN 1337-8384, eISSN 2453-711X 
MAKOVSKY, M.M. 1989. A wonderful world of words and meanings: illusions and paradoxes in vocabulary and semantics. Moscow: Vysshaya shkola. ISBN 978-5-06000183-9

MAKOVSKY, M.M. 1992. Linguistic Genetics: Problems of the ontogenesis of words in Indo-European languages. Moscow: Nauka. ISBN 978-5-02-017114-5

MAKOVSKY, M.M. 1996. A comparative dictionary of mythological symbols in Indo-European languages: the image of the world and the worlds of images. Moscow: Gumanitarnyj izdatelsky tsentr VLADOS. ISBN 5 -87065-101-8

MAKOVSKY, M.M. 1999. Historical and etymological dictionary of modern English. Moscow: Publishing house «Dialog». ISBN 5-93883-013-5

MAKOVSKY, M.M. 2002. Semiotics of Pagan Cults (Mythopoetic Etudes). In: Voprosy yazykoznaniya, vol. 6, pp. 55-81. ISSN 0373-658X

MAKOVSKY, M.M. 2004. Etymological Dictionary of Modern German: A Word in the Mirror of Human Culture. Moscow: Azbukovnik. ISBN 5-98455-005-9

MAKOVSKY, M.M. 2005. A large etymological dictionary of modern English: A word in the mirror of human culture. Moscow: Azbukovnik. ISBN 5-98455-015-6

MAKOVSKY, M.M. 2007. Mythopoetic etudes. In: Voprosy yazykoznaniya, vol. 2, pp. 35-56. ISSN 0373-658X

MAKOVSKY, M.M. 2012. The phenomenon of taboo in the traditions and language of Indo-Europeans: Essence, forms, development. Moscow: Knizhny dom «LIBROKOM». ISBN 978-5-397-02224-8

MAKOVSKY, M.M. 2013. Indo-European etymology: Subject, methods, practice. Moscow: Knizhny dom «LIBROKOM». ISBN 978-5-397-00029-1

PATTRIDGE, E. 2009. Origins: A Short Etymological Dictionary of Modern English. London-New York: Routledge, Taylor\&Francis Group. ISBN 0415-474337

PERRING, D. 1991. Roman London: The Archaeology of London. London: Seaby. ISBN 978-1-852-64039-2

SEMENOV, A.V. 2003. Etymological dictionary of the Russian language: Series «Russian language from A to $Z$ ». Moscow: Publishing house «YUNVES». ISBN 588682-149-X

TOPOROVA, T.V. 1994. The semantic structure of the ancient German world model. Moscow: Publishing house «Radiks». ISBN 5-86463-036-5

TUMANOVA, O.S. 2001. The concept of the world tree (culturological aspect): author's abstract of candidate's thesis. Rostov-on-Don

VORFOLOMEEVA, Yu.I. 2012. Mythologem of sound in Indo-European languages (lexico-etymological and linguocultural research): author's abstract of candidate's thesis. Moscow.

WARTBURG, W. 1969. Französisches etymologisches Wörterbuch. Bd. 3. Tübingen:

J. C. B. Mohr (Paul Siebeck).

Words: 10327

Characters: 76854 (44,36 standard pages)

Associate professor Nataliya A. Kindrya, PhD.

Language Training Department

Financial University under the Government of the Russian Federation

125993 (GSP-3), 49 Leningradsky prospekt

Moscow,

Russian Federation

nkindrya@mail.ru

Andrei V. Mitichkin

major Linguistics, specialty Theory and Practice of Translation

Novosibirsk State University 
300901 Pirogova str.

Novosibirsk,

Russian Federation

killamoon112@gmail.com 